\title{
Relationship between soil diversity and inhabitant mites (Acari)
}

\author{
M. M. E. Elmoghazy ${ }^{*}$ and S. S. Shawer** \\ *Agric. Zoology and Nematology Dept., Fac. of Agric., Alazhar Univ., Cairo, Egypt \\ ${ }^{* *}$ Soils and Water Dept., Fac. of Agric., Alazhar Univ., Cairo, Egypt
}

\begin{abstract}
Mites are important regulators of soil food webs in the ecosystem. Soil diversity, $\mathrm{pH}$, electrical conductivity and organic matters are dominant disturbance factors on community composition of soil mites. Impacts of these factors were assessed on the species composition of soil mites at Dakahleia and Kafrelshikh governorates in six different sites. In total, 14 families, 30 genera, and 37 mite species belonging to the four sub-orders Gamasida, Actinedida, Oribatida and Acaridida were recorded. Mite abundance and diversity in the soil in Kafrelshikh was poor compared with Dakahleia sites. The effect of soil type on mite community composition was significant. PH and organic matters have been established as good indicators for soil fertility. Soil mites were affected by soil fertility as it was observed that soil mites population increased with increasing nutrients. This study provided important information on soil mite populations in cultivated soils and could provide baseline data for studies of bioindicators of soil quality. In conclusion soil mites responded to land type, $\mathrm{pH}, \mathrm{EC}(\mathrm{ds} / \mathrm{m})$ and organic matter level.
\end{abstract}

Key Words: Soil mites, Gamasida, Actinedida, Oribatida, Acaridida, Soil diversity, Organic matters, Soil fertility.

\section{INTRODUCTION}

The environment of soil organisms in managed ecosystems can be influenced by land use factors, such as tillage, pesticides and fertilizers application, soil compaction during harvest, and removal of plant biomass. The responses of soil communities to land management, quantified as changes in abundance, species richness and diversity indices, have generally been examined at habitat-wide scales (Vreeken-Buijs et al., 1998). Soil tillage, application of biocides, reduction of vegetation cover and the consequent changes in microclimate have been reported to have negative effects on survival and reproduction of soil microarthropods in arable fields (Badejo and Straalen, 1993). Agricultural practices alter not only the abundance and dynamics of different organisms and nutrients in the soil, but also affect the structure and dynamics of the food webs (Moore, 1994). The soil microflora and fauna complement each other in commutation of litter, mineralization of essential plant nutrients and conservation of these nutrients within the soil system (Marshall, 2000). Soil mites are abundant soil organisms that are sensitive to soil perturbations in agricultural practices and their number and diversity often get reduced affecting their ecosystem services (Minor and Cianciolo, 2007). Several genera of soil mites are considered good bio-indicators of habitat and soil conditions (Behan-Pelletier, 1999). Several studies have been conducted to study the distribution and abundance of soil mites at different locations in Egypt (Kandeel, 1993; El-Moghazy, 2006 and El-Sharabasy, 2010).
The objective of this study was to determine the effect of soil diversity, soil water-table depth and fertilization in different sites in Dakahleia and Kafrelshikh governorates north of Nile Delta, on abundance and diversity of soil mites.

\section{MATERIALS AND METHODS}

\section{Extraction and preparation of mite specimens:}

The samples were taken from soil at six locations, three from Talkha district in Dakahleia and three from Motoubas district in Kafrelshikh governorates, Egypt, monthly during winter and spring seasons (December 2010 to May 2011). The samples in Dakahleia were taken from soil under potatoes, wheat and clover cultivars, while those in Kafrelshikh were taken from soil under guava trees orchard. Three soil samples were taken from $(0-20$ $\mathrm{cm}$ depth) by iron rectangle $(6 \times 6 \times 8$ inch), one $\mathrm{Kg}$ /sample, at each location then were put singly in tightly closed polyethylene bags. In the laboratory, mites were extracted from soil samples using Berlese-Tullgren funnel (Lasebikan, 1974). Receiving the extraction (mites and other arthropods) in aquatic medium that helped in purification and prohibit escaping mites. Extracted mites were then transferred to solution containing ethanol and acetic acid at 9: 1 ratio, sudden death solution, which quickly killed mites and stretched their bodies. After that, mites were transferred to clearing solution such as Nesbitt's solution or lactic acid for a period depending on mite species and its inflexible degree. Mite individuals were picked from clearing solution and singly mounted in Hoyer's 
medium on glass slides and sample data were recorded on each side.

\section{Mite identification:}

Mites classification was defined according to Bregetova (1977), Krantz (1978) and Zaher (1986) as well as comparing them with those already identified in the Laboratory.

\section{Soil analysis:}

The soil sample $(0-20 \mathrm{~cm}$ depth) was routinely analyzed according to Klute (1986) for physical properties; and according to Page et al., (1982) for chemical properties (EC, $\mathrm{pH}$ and soluble ions).

Available $\mathrm{P}, \mathrm{Fe}, \mathrm{Mn}, \mathrm{Zn}$ and $\mathrm{Cu}$ were extracted according to the methods of Soltanpour (1991) by mixture solution of Diethylene Triamine pent acidic acid $97 \%$ (DTPA) and ammonium bicarbonate with adjusting at $\mathrm{pH} 7.6$, soil sample $(20 \mathrm{gm})$ were shaken with $40 \mathrm{ml}$ from the mixture solution to about 15 minutes then filtered. Determine of $\mathrm{P}, \mathrm{Fe}, \mathrm{Mn}, \mathrm{Zn}$ and $\mathrm{Cu}$ was carried out in this extract using Inductively Coupled Plasma (ICP) spectrometry, (Ultima 2 JY plasma), potassium was determined by flame photometer and available nitrogen was determined by using Kjeldahl method according to Jackson (1973).

\section{RESULTS AND DISCUSSION}

\section{Abundance and Diversity of the soil mites:}

In total, 14 families of 30 genera, and 37 mite species were collected. The Gamasida (seven families) and Actinedida (five families) were the most-abundant taxa, followed by the Acaridida and Oribatida as one family for each were recorded.

Cheyletidae and Acaridae were the most diverse families, with five species for each, followed by Ascidae and Oppiidae with four species and Uropodidae \& Cunaxidae with three species for each. Then other families followed with two or one species each (Tables 1 and 2).

Out of 37 species, six species were found in four sites. These were Protogamasellus denticus Nasr, Hypoaspis bregetova Shereef and Afifi, Parasitus consanguineus Oudemans and Voigts, Uroobovella varians Hirschmann, Cheletomorpha lepidopterorum (Shaw) and Cunaxa setirostri (Hermann). Site factors had remarkable effect on the diversity of soil mites. The overall structure of mite assemblages was significantly related to soil type.
These results were in agreement with that of Maraun and Scheu (2000) who observed that effect of soil type on community composition of both Oribatida and Mesostigmata was significant, confirming that species with different life history tactics were differently filtered from soil communities by land management practices

\section{The relationship between $\mathrm{PH}, \mathrm{EC}(\mathrm{ds} / \mathrm{m})$ and organic matter in soils on community composition of soil mites:}

Data on soil PH, EC (ds/m), organic matter content and statistics poll for each species/genus/family of soil mites extracted from the studied plots is presented in table (3). The abiotic conditions observed in soil at different sites in Dakahleia were suitable for the development of a high-diversity soil mite community as organic matters therein were relatively higher compared with those in Kafrelshikh, where soil organic matter contents as low as $0.5 \%$ was recorded.

The highest community composition in soil was recorded in different sites in Dakahleia (Tables 1 and 2). From the obtained results, $\mathrm{pH}$ and organic matters have been established as good indicators for soil fertility and thereafter enhanced favorable conditions for soil mites flourish (Table 3).

These results are in agreement with Badejo and Ola-Adams (2000) who observed if data on PH and organic matter which have been established as good indicators of soil fertility show a trend of fertility decline in the plantations, it follows therefore that low cryptostigmatid mite density indicates low fertility. Organic matter is a source and a sink for nutrient elements in the soil. It has appreciable influence on many soil properties, hence its significance in maintenance of soil fertility (Swift \& Woomer, 1993). The findings of Tian et al., (1998) showed that microarthropods have a buffering effect in regulating leaf decomposition and nutrient release. Environmental factors such as high soil organic matter content and nearly neutral PH levels are favorable conditions for soil mite development. It is well known that high soil organic matter content is usually beneficial for most soil animal groups (Bandyopadhyaya et al., 2002). Freeliving soil gamasid mites are important regulators of decomposition processes in forest soil ecosystems and occupy a high trophic level in the soil decomposition food web (Schneider and Maraun, 2009). Consequently, the presence of gamasid mites may reflect overall physicochemical conditions of soil, including organic matter, microflora (fungi and bacteria), microfauna (nematodes), and mesofauna (collembolans, oribatids and other mites) (Walter et al., 1988). 
Table (1):- List of predaceous mites diversity at different sites

\begin{tabular}{|c|c|c|c|c|c|c|}
\hline \multirow{2}{*}{ Mites } & \multicolumn{3}{|c|}{ Dakahleia } & \multicolumn{3}{|c|}{ Kafrelshikh } \\
\hline & 1 & 2 & 3 & 1 & 2 & 3 \\
\hline \multicolumn{7}{|l|}{$\begin{array}{l}\text { Gamasida } \\
\text { Ascidae Voigts and Oudmans }\end{array}$} \\
\hline Protogamasellus denticus Nasr & + & & + & & + & + \\
\hline Proctolaelaps pygmaeus (Müller) & ++ & + & & & & \\
\hline Lasioseius africanus $\mathrm{Nasr}$ & + & & + & & & \\
\hline L. aegypticus Afifi & + & + & & & & \\
\hline \multicolumn{7}{|l|}{ Laelapidae Berlese } \\
\hline Laelaspis astronomicus (Koch) & + & ++ & & & & \\
\hline Hypoaspis bregetova Shereef and Afifi & + & & + & & + & + \\
\hline \multicolumn{7}{|l|}{ Macrochelidae Vitzthum } \\
\hline Macrocheles merdarius (Berlese) & & + & + & & & + \\
\hline \multicolumn{7}{|l|}{ Ologamasidae Ryke } \\
\hline Gamasiphis parpulchellus Nasr and Mersal & + & & + & & & \\
\hline \multicolumn{7}{|l|}{ Parasitidae Oudemans } \\
\hline Parasitus consanguineus Oudemans and Voigts & + & + & & & + & + \\
\hline \multicolumn{7}{|l|}{ Uropodidae Berlese } \\
\hline Urobovella varians Hirschmann & + & + & + & & & + \\
\hline U. ovalis Hirschmann & + & & & & & \\
\hline Uropoda sp. & + & & ++ & & & \\
\hline \multicolumn{7}{|l|}{$\begin{array}{l}\text { Actinedida } \\
\text { Cheyletidae Leach }\end{array}$} \\
\hline Cheyletus trouessarti Oudemans & +++ & & & & & + \\
\hline C. aversor Rohdendorf & & + & + & & & + \\
\hline Acaropsellina sollers Rohdendorf & + & & + & & & \\
\hline Cheletomorpha lepidopterorum (Shaw) & + & ++ & & + & + & \\
\hline Cheletogenes ornatus (Can. and Fanz.) & + & + & & & & \\
\hline \multicolumn{7}{|l|}{ Cunaxidae Thor } \\
\hline Cunaxa setirostris (Hermann) & ++ & + & & & + & + \\
\hline Pulaeus glebulentus Den Heyer & & + & + & & & \\
\hline Pseudocunaxa sp. & + & & + & & & \\
\hline \multicolumn{7}{|l|}{ Raphignathidae Kramer } \\
\hline Raphignathus gracilis (Rack) & ++ & + & + & & & \\
\hline Raphignathus sp. & & + & & & & \\
\hline \multicolumn{7}{|l|}{ Stigmaeidae Oudemans } \\
\hline Apostigmaeus navicella Grandjean & + & & ++ & & & \\
\hline Stigmaeus sp. & + & & & & & \\
\hline
\end{tabular}

Table (2):- List of miscellaneous feeding mites diversity at different sites

\begin{tabular}{|c|c|c|c|c|c|c|}
\hline \multirow{2}{*}{ Mites } & \multicolumn{3}{|c|}{ Dakahleia } & \multicolumn{3}{|c|}{ Kafrelshikh } \\
\hline & 1 & 2 & 3 & 1 & 2 & 3 \\
\hline \multicolumn{7}{|l|}{$\begin{array}{l}\text { Gamasida } \\
\text { Ameroseiidae Evans }\end{array}$} \\
\hline Ameroseius ulmi (Berhard) & & + & & & + & \\
\hline Kleemannia plumosus (Oudemans) & + & & + & & & \\
\hline \multicolumn{7}{|l|}{$\begin{array}{l}\text { Actinedida } \\
\text { Tarsonemidae Kramer }\end{array}$} \\
\hline Iponemus sp. & ++ & & & & & \\
\hline Tarsonemus sp. & + & ++ & & & & \\
\hline \multicolumn{7}{|l|}{$\begin{array}{l}\text { Oribatida } \\
\text { Oppiidae Grandjean }\end{array}$} \\
\hline Oppia concolor Koch & ++ & + & & & & \\
\hline O. sticta Popp & ++ & & + & + & & \\
\hline Oppia sp. & +++ & & & & & \\
\hline Oppiella sp. & & & & & & + \\
\hline \multicolumn{7}{|l|}{$\begin{array}{l}\text { Acaridida } \\
\text { Acaridae Leach }\end{array}$} \\
\hline Acarus siro $\mathrm{L}$. & ++ & ++ & & & + & \\
\hline Tyrophagus palmarum Oudemans & & + & ++ & & & \\
\hline T. putrescentiae (Schrank) & + & & & & & \\
\hline Tyrolichus casei Oudemans & + & ++ & + & & & \\
\hline Caloglyphus berlesei (Michael) & & + & & & & \\
\hline
\end{tabular}

\footnotetext{
$+=(<6) \quad++=(6-12) \quad+++=(>12)$ mite/sample
} 
Table (3): Soil PH, EC (ds/m), organic matter and composition of mites in soil at different sites

\begin{tabular}{lcccccc}
\hline \multirow{2}{*}{ Parameters } & \multicolumn{3}{c}{ Dakahleia } & \multicolumn{3}{c}{ Kafrelshikh } \\
\cline { 2 - 7 } & 1 & 2 & 3 & 1 & 2 & 3 \\
\hline PH $(1: 2.5)$ & 7.40 & 7.47 & 7.71 & 8.15 & 7.83 & 7.60 \\
\hline EC(ds/m) & 0.52 & 0.40 & 0.61 & 3.2 & 1.12 & 0.52 \\
\hline Organic mater \% & 1.85 & 1.67 & 1.34 & 0.08 & 0.09 & 0.16 \\
\hline Family & 13 & 12 & 12 & 2 & 5 & 9 \\
\hline Genus & 25 & 19 & 17 & 2 & 6 & 8 \\
\hline Species & 29 & 20 & 17 & 2 & 6 & 9 \\
\hline
\end{tabular}

Table (4):- Some physical and chemical properties of investigated soil

\begin{tabular}{|c|c|c|c|c|c|c|c|c|c|c|c|c|c|c|}
\hline \multirow{2}{*}{ Location } & \multicolumn{4}{|c|}{ Particle size distribution } & \multirow{2}{*}{ Texture } & \multirow{2}{*}{ SP } & \multicolumn{8}{|c|}{ Soluble ions (meq/l) } \\
\hline & & Sand & Silt & Clay & & & $\mathrm{Ca}^{++}$ & $\mathrm{Mg}^{++}$ & $\mathrm{Na}^{+}$ & $\mathrm{K}^{+}$ & $\mathrm{CO}_{3}^{-}$ & $\mathrm{HCO}_{3}{ }^{-}$ & $\mathrm{SO}_{4}^{-}$ & $\mathrm{Cl}^{-}$ \\
\hline \multirow{3}{*}{ Dakahleia } & 1 & 10.0 & 10.7 & 79.3 & Clay & 45.5 & 1.20 & 0.60 & 1.27 & 1.40 & - & 2.17 & 1.10 & 1.30 \\
\hline & 2 & 11.1 & 12.4 & 76.5 & Clay & 45.4 & 1.02 & 0.50 & 1.09 & 1.19 & - & 1.80 & 0.80 & 1.20 \\
\hline & 3 & 11.9 & 12.5 & 75.6 & Clay & 45.8 & 1.60 & 0.90 & 0.67 & 2.10 & - & 1.90 & 2.10 & 1.36 \\
\hline \multirow{3}{*}{ Kafrelshikh } & 1 & 75.3 & 13.0 & 11.7 & Sandy loam & 37.50 & 7.51 & 9.55 & 14.43 & 0.49 & - & 1.50 & 4.58 & 25.90 \\
\hline & 2 & 82.0 & 9.4 & 8.6 & Sandy loam & 36.50 & 2.00 & 3.55 & 5.41 & 0.22 & - & 0.50 & 1.18 & 9.50 \\
\hline & 3 & 72.6 & 15.3 & 12.1 & Sandy loam & 36.2 & 1.20 & 0.81 & 1.32 & 1.11 & - & 2.2 & 1.10 & 1.32 \\
\hline
\end{tabular}

Table (5):- Some nutrients content in the investigated soil sample

\begin{tabular}{|c|c|c|c|c|c|c|c|c|}
\hline Location & No. & Macro-1 & ts, av & m) & Micro & s, ava & & \\
\hline \multirow{4}{*}{ Dakahleia } & & $\mathrm{N}$ & $\mathrm{P}$ & $\mathrm{K}$ & $\mathrm{Fe}$ & $\mathrm{Mn}$ & $\mathrm{Zn}$ & $\mathrm{Cu}$ \\
\hline & 1 & 85.81 & 1.10 & 54.60 & 18.57 & 1.27 & 0.59 & 5.14 \\
\hline & 2 & 73.50 & 2.22 & 46.41 & 10.20 & 1.62 & 0.72 & 5.16 \\
\hline & 3 & 183.75 & 3.24 & 81.90 & 25.07 & 2.35 & 1.64 & 6.78 \\
\hline \multirow{3}{*}{ Kafrelshikh } & 1 & 4.81 & 0.50 & 6.60 & 3.88 & 2.3 & 1.80 & 1.10 \\
\hline & 2 & 6.40 & 0.42 & 7.14 & 2.99 & 2.14 & 1.72 & 0.86 \\
\hline & 3 & 5.82 & 0.43 & 8.15 & 3.4 & 2.4 & 1.50 & 0.95 \\
\hline
\end{tabular}

General effects of soil $\mathrm{PH}$ and salinity on community composition of soil mites:

Slightly alkaline soil PH in range from 7.0 to 8.15 occurred in Kafrelshikh locations that contain large amounts of naturally-occurring water sea. This high water sea may lead to change in soil PH. Irrigation of low quality waters also may cause this high soil PH change.

Salinity affects plant growth through ionic and osmotic effects as well as community composition of soil mites. Sometimes these effects are distinct from each other; while sometimes these effects overlap.

Based on the total salt concentration in soils extract; it is usually measured by electrical conductivity, EC in units of $\mathrm{dS} / \mathrm{m}$, where the brackets refer to the concentration in soil solution or the saturated paste extract. In slightly salinity soils, soil colloids disperse, disrupting soil structure and water physical change in soil structure has severe consequences on community composition of soil mites in addition to the direct effects of the slightly increase saline solutions. Slightly increase salts soil range (EC 0.52 to $3.20 \mathrm{dS} / \mathrm{m}$ ) in locations of Kafrelshikh as it contains large amounts of naturally-occurring water sea. This high water sea may be due to change in soil extract EC. Irrigation low quality waters may be due to change high soil extract EC and also high soil water table. In saltstressed plants, slightly increase saline-sodic conditions. Also this may affect plant nutrition, growth, water and ion transport in plants in addition to mites abundance, population densities and diversity in the soil. A major problem in slightly alkaline soils is reduced nutrient, and especially micronutrient, availability. Based on the above data of tables (3, 4 and 5) locations of Dakahleia contain large amounts of macronutrients and micronutrients and low salts soil range (EC 0.40 to $0.61 \mathrm{dS} / \mathrm{m}$ ) and range $\mathrm{PH} 7.4$ to 7.71 ; compared with locations of Kafrelshikh.

Finally, it can be concluded that low soil mites densities signify poor fertility in cultivated soils. The habitat fragmentation leads to fragmentation of the soil mites community and alteration of their diversity. PH and organic matter have been established as good indicators for soil fertility, as well as soil mites density. Type of vegetation cover and the resulting litter as well as intensive agriculture affect mite population densities and diversity in the soil. The difference in soil mites 
community is affected by natural salinity concentration and composition of the ions in solution.

\section{REFERENCES}

Badejo, M. A. and Ola-Adams, B. A. 2000. Abundance and diversity of soil mites of fragmented habitats in a biosphere reserve in southern Nigeria. Pesq. agropec. bras., Brasília, 35(11): 2121-2128.

Badejo, M. A. and Straalen, N. M. van. 1993. Seasonal abundance of springtails in two contrasting environments. Biotropica, Washington, 25: 222 - 228.

Bandyopadhyaya, I.; Choudhuri, D. K. and Ponge, J. F. 2002. Effects of some physical factors and agricultural practices on Collembola in a multiple cropping programme in West Bengal (India). Eur. J. Soil Biol., 38: 111 - 117.

Behan-Pelletier, V. M. 1999. Oribatid mite biodiversity in agroecosystems: role for bioindication. Agriculture Ecosystems and Environment., 74: 411 - 423.

Bregetova, N. G. 1977. Identification key of soil inhabiting mites. Mesostigmata. Nauka, Leningrad, 717pp.

El-Moghazy, M. M. E. 2006. Ecological, taxonomical and biological studies on some economic mites. Ph. D. Thesis, Faculty of Agriculture, Al-Azhar University, 206 pp.

El-Sharabasy, H. M. 2010. Abundance and diversity of soil mites (Acari: Gamasida \& Oribatida) in mango orchards in Ismailia region, Egypt. Acarines, 4: 31 - 36.

Jackson, N. L. 1973. Soil chemical analysis Prentic Hall of Indian, private limited, New Delhi.

Kandeel, M. M. H. 1993. Annotated lest and keys to mites occurring in North Sinai, Egypt. J. Product. \& Dev., I (1): 55 - 80.

Klute, A. 1986. Methods of soil analysis. Part 1. Physical and Mineralogical Methods ( $2^{\text {nd }}$ ed.) Amer. Soc. Agron. Monograph No. 9 Madison, Wisconsin, USA.

Krantz G. W. 1978. A manual of acarology, 2nd Ed., Corvallis: Oregon State University Book Stores Inc., 509 pp.

Lasebikan, B. A. 1974. A preliminary communication on microarthropods from a tropical rainforest in Nigeria. Pedobiologia, Jena, 14: 402 - 411.

Maraun, M. and Scheu, S. 2000. The structure of oribatid mite communities (Acari, Oribatida): patterns, mechanisms and implications for future research. Ecography, 23: 374 - 383.

Marshall, V. G. 2000. Impacts of forest harvesting on biological processes in northern forest soils. Forest Ecology and Management, 133: 43 - 60.

Minor, M. A. and Cianciolo, J. M. 2007. Diversity of soil mites (Acari: Oribatida, Mesostigmata) along a gradient of LUTs in New York. Applied Soil Ecology, 35: 140 - 153.

Moore, J. C. 1994. Impact of agricultural practices on soil food web structure: Theory and application. Agriculture Ecosystems and Environment, 51: 239 - 247.

Page, A. L.; Miller R. H. and Keeny D. R. 1982. Methods of soil analysis. Part II. Chemical and microbiological properties ( $2^{\text {nd }}$ ed.) Amer. Soc. Agron. Monograph no. 9 Madison, Wisconsin, USA.

Schneider, K. and Maraun, M. 2009. Top-down control of soil microarthropods-evidence from a laboratory experiment. Soil Biol. Biochem., 41: $170-175$.

Soltanpour, P. N. 1991. Determination of nutrient availability element toxicity by AB- DTPA. soil test and ICPS Adv. Soil Sci., 16: $165-190$.

Swift, M. J. and Woomer, P. 1993. Organic matter and the sustainability of agricultural systems: definition and measurement. In: Mulongoy, K.; Merckx, R. (Ed.). Soil organic matter dynamics and sustainability of tropical agriculture. Leuven : IITA/J. Wiley, 3 - 18.

Tian, G.; Adejuyigbe, C. O.; Adeoye, G. O. and Kang, B. T. 1998. Role of soil microarthropods in leaf decomposition and release under various land-use practices in the humid tropics. Pedobiologia, Jena, 42: 33 - 42.

Vreeken-Buijs, M. J.; Hassink, J. and Brussaard, L. 1998. Relationships of soil microarthropod biomass with organic matter and pore size distribution in soils under different land use. Soil Biol. Biochem., 30: 97 - 106.

Walter, D. E.; Hunt, H. W. and Elliott, E. T. 1988. Guilds or functional groups. An analysis of predatory arthropods from a short grass steppe soil. Pedobiologia, 31: 247 - 260.

Zaher, M. A. 1986. Survey and ecological studies on phytophagous, predaceous and soil mites in Egypt. II Predaceous and non phytophagous mites in Egypt. (Nile Vally Delta). Final Report of PL- 480 Programme, U.S.A., Project No.EGARS 30, Grant No. FG-EG-139, 567 pp. 